\title{
Seismic Imaging and Reservoir Architecture of Sub-Marine Channel Systems Offshore West Nile Delta of Egypt
}

\author{
Essam Sharaf ${ }^{1}$, Ibrahim Korrat ${ }^{1}$, Hamdy Seisa ${ }^{1}$, Eslam Esmaiel ${ }^{2}$ \\ ${ }^{1}$ Geology Department, Faculty of Science, Mansoura University, Mansoura, Egypt \\ ${ }^{2}$ Department of Production Management, PETRONAS (PICL) Egypt, Helwan, Egypt \\ Email: islam esmaiel@yahoo.com
}

Received 19 October 2014; revised 15 November 2014; accepted 8 December 2014

Copyright (C) 2014 by authors and Scientific Research Publishing Inc.

This work is licensed under the Creative Commons Attribution International License (CC BY).

http://creativecommons.org/licenses/by/4.0/

c) (i) Open Access

\begin{abstract}
Offshore Nile Delta gas reservoirs are dominated by slope-channel systems of Plio-Pleistocene age. High-quality, three-dimensional seismic imaging has significantly helped in defining the geomorphology and architectures of these channels. Integrating seismic, logs and core data from four wells resulted in understanding of different stages of channel development and reservoir quality. The studied reservoirs that are largely controlled by episodes of transgressive-regressive events resulted in deposition of fine grained sediment and shale. Sienna channel complex consists of unconfined channel system with clearly defined development stages. The stages include amalgamated or stacked channels followed by channel abandonment phases and local flooding events. The depositional pattern continued through the Late Pliocene-Pleistocene. SimSat-P1 and SimSat-P2 reservoirs are characterized by isolated sand bodies, most probably relics of fan depositional setting. The depositional scenario that is largely controlled by successive transgression and flooding events resulted in deposition of interbedded, sheet-like, fine grained sediment and shale.
\end{abstract}

\section{Keywords}

Offshore Nile Delta, Western Nile Delta, Seismic, Reservoir Architecture, Submarine Channel System

\section{Introduction}

Rapid increase in the industrial activities soars the demand for huge additional energy sources especially the

How to cite this paper: Sharaf, E., Korrat, I., Seisa, H. and Esmaiel, E. (2014) Seismic Imaging and Reservoir Architecture of Sub-Marine Channel Systems Offshore West Nile Delta of Egypt. Open Journal of Geology, 4, 718-735. 
fossil fuel. As a result, the exploration started in frontier areas such as deep marine, structurally and stratigraphically complex and unconventional areas looking for additional recoverable reserves of both oil and gas to satisfy the growing demand of energy.

An increase in the hydrocarbon exploration of deep-water Tertiary Basins, coupled with the acquisition of large, high-quality 3-D seismic data sets, has led to a considerable focus on deep-water depositional systems. Well documented seismically-based examples include offshore Angola [1]; offshore Nigeria [2]; the Gulf of Mexico [3] [4].

Models for deep-water slope settings and classifications for the associated channel elements are provided by [5]. The role of these slope turbidites as hydrocarbon reservoirs has been emphasized by [1] [6] [7].

Despite the numerous seismically-based examples of deep-water systems in the literature, there is a relative scarcity of published examples about detailed 3-D architecture of composite canyon fills that have been described using high-quality seismic data. Few examples are derived from Pleistocene sections offshore Nile Delta of Egypt where it is possible to integrate several data types (e.g., cores, logs, pressure data, etc.). The seismic-stratigraphy of the Pliocene deep-water canyon-filling reservoirs of the offshore west Nile Delta was first described by [8].

The Nile Delta is one of the classical deltas in the world, with a great history created by the different civilizations. Beside its great history, the Nile Delta area is one of the major gas provinces and one of the most promising areas for future petroleum exploration in north eastern Africa. Offshore exploration, using high quality 3-D seismic data, has resulted in the discovery of significant reserves up to 42 TCF with approximately 50 TCF (Trillion Cubic feet) yet to find [9].

The Nile Delta is located in northern Egypt (Figure 1), where the Nile River spreads out and drains into the Mediterranean Sea. It has an area of about $12,500 \mathrm{~km}^{2}$, very flat at the north and reaches up to $18 \mathrm{~m}$ above sea level at Cairo. The Nile Delta is considered one of the world's largest river deltas. It covers approximately 230 $\mathrm{km}$ of Mediterranean coastline from Alexandria in the west to Port Said in the east. The outer edges of the delta are eroding, and some coastal lakes such as El Manzala and Burulls have experienced an increasing salinity levels as their connection to the Mediterranean Sea increases.

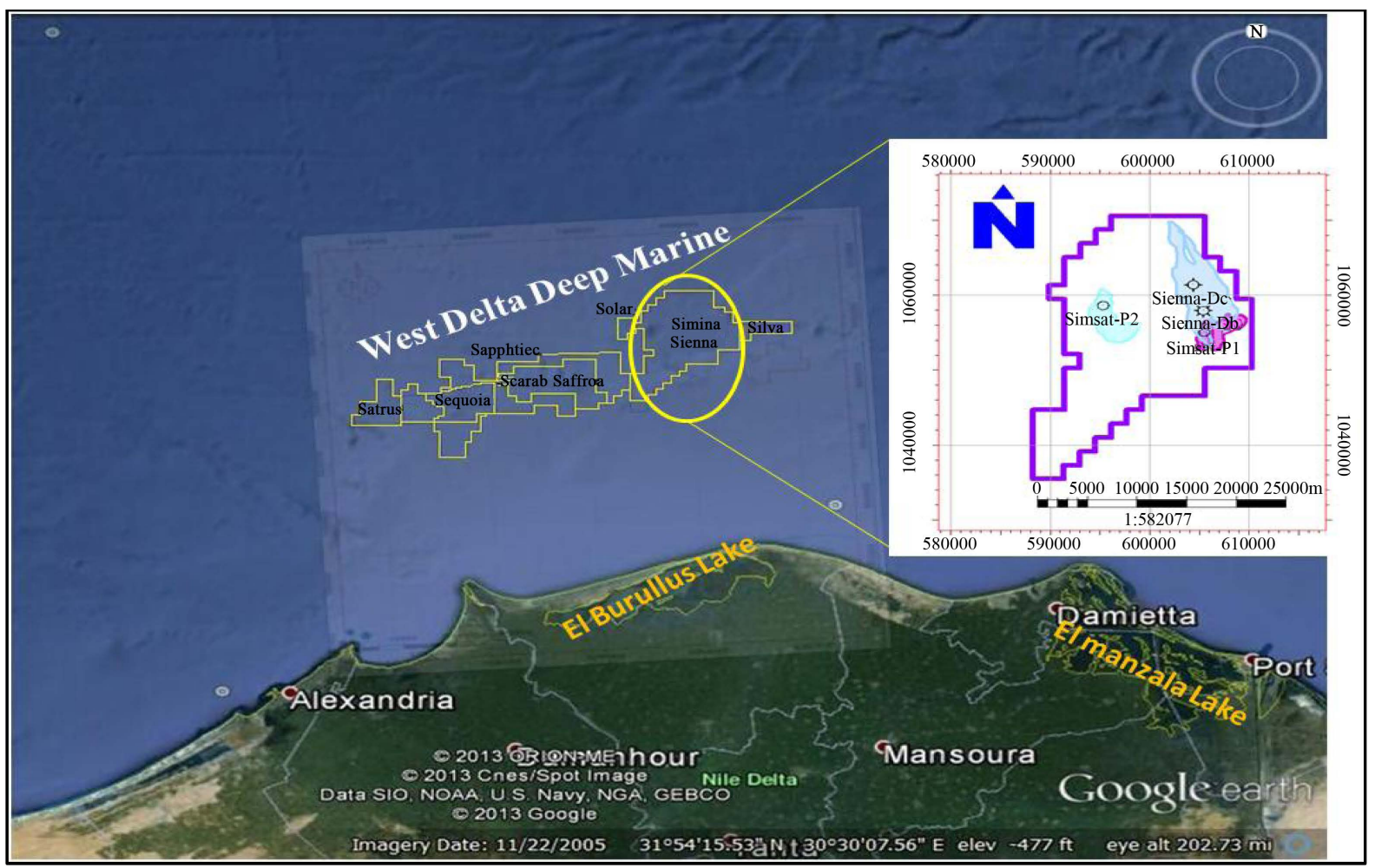

Figure 1. Satellite map for onshore and offshore Nile Delta part showing West Delta Deep marine (WDDM) concession location relative to the current shore line and a pop up map showing Simian/Sienna development lease (study area). 


\section{Field Locations and Exploration History}

The study area is part of the West Delta Deep Marine (WDDM) license which extends from 90 to $100 \mathrm{~km}$ offshore (250 - $1500 \mathrm{~m}$ water depth) of the present Nile Delta.

The WDDM license covers $8200 \mathrm{~km}^{2}$ on the north-western margin of the Nile delta cone. Exploration activities at WDDM started in 1997. A series of successive successful exploration and appraisal wells were drilled by British Gas (BG)-Egypt and Rashpetco. The main drilling target was the Pliocene gas-bearing sands in slope canyon settings on the concession. Several wells were drilled along these canyons namely, from west to eastSaurus, Sequoia, Saffron, Scarab, Sapphire, Serpent, Simian and Sienna (Figure 1). Sequoia, Saffron, Scarab, Serpent and Sienna are of Early Pliocene. Saurus and Sienna canyons were drilled in the Middle Pliocene age. Sapphire reservoir is another relatively deeper reservoir of the Late Pliocene age.

The studied area contains Simian and Sienna fields, located in WDDM in Simian/Sienna development lease. The fields are approximately 120 kilometers offshore Idku, near Alexandria (Figure 1).

The Simian field was discovered by BG-Egypt. The first well, the Simian-l was drilled in 1999. Simian is a combined stratigraphic-structural trap with dip-closure along the northern and southern margins. The Simian field consists of a number of deep marine channels constrained within a NNE-SSW trending initial channel valley cut. Simian channel system consists of two main branches which merge to the north where the maximum width of the field is over $4.5 \mathrm{~km}$ [10]. The SimSat-P1 reservoir is a thin, sheet-like channel system. The reservoir is located at the eastern side of the study area; it is shallower than the main Simian Field (Figure 2). The first discovery well is SimSat-P1 which is located approximately $125 \mathrm{~km} \mathrm{NE}$ of Alexandria in the Eastern portion of the WDDM concession. Water depth at the well location is approximately $891 \mathrm{~m}$.

The Sienna field is located to the east of Simian. The Sienna field trends NNW-SSE and directly overlies the northernmost part of Simian. Sienna is also a combined structural-stratigraphic trap and has two main branches. The western branch is a typical WDDM channel trend (NNE-SSW) and is confined within a canyon cut. The eastern branch is a combination of channel and sheet sand, which have spilled from the main western channel.

The importance of this study is that it provides an example of integrating different pieces of subsurface data to build a comprehensive geologic understanding of one of the most promising gas potentials in Egypt. The objectives of this paper are to: interpret the main depositional environments of the Plio-Pleistocene reservoirs at the studied area based on seismic, logs and core data; define the depositional architectures and evolution through time; map the regional extension of the reservoir channel bodies by using detailed seismic interpretation; and evaluate the reservoir quality based on the available petrophysical analyses.

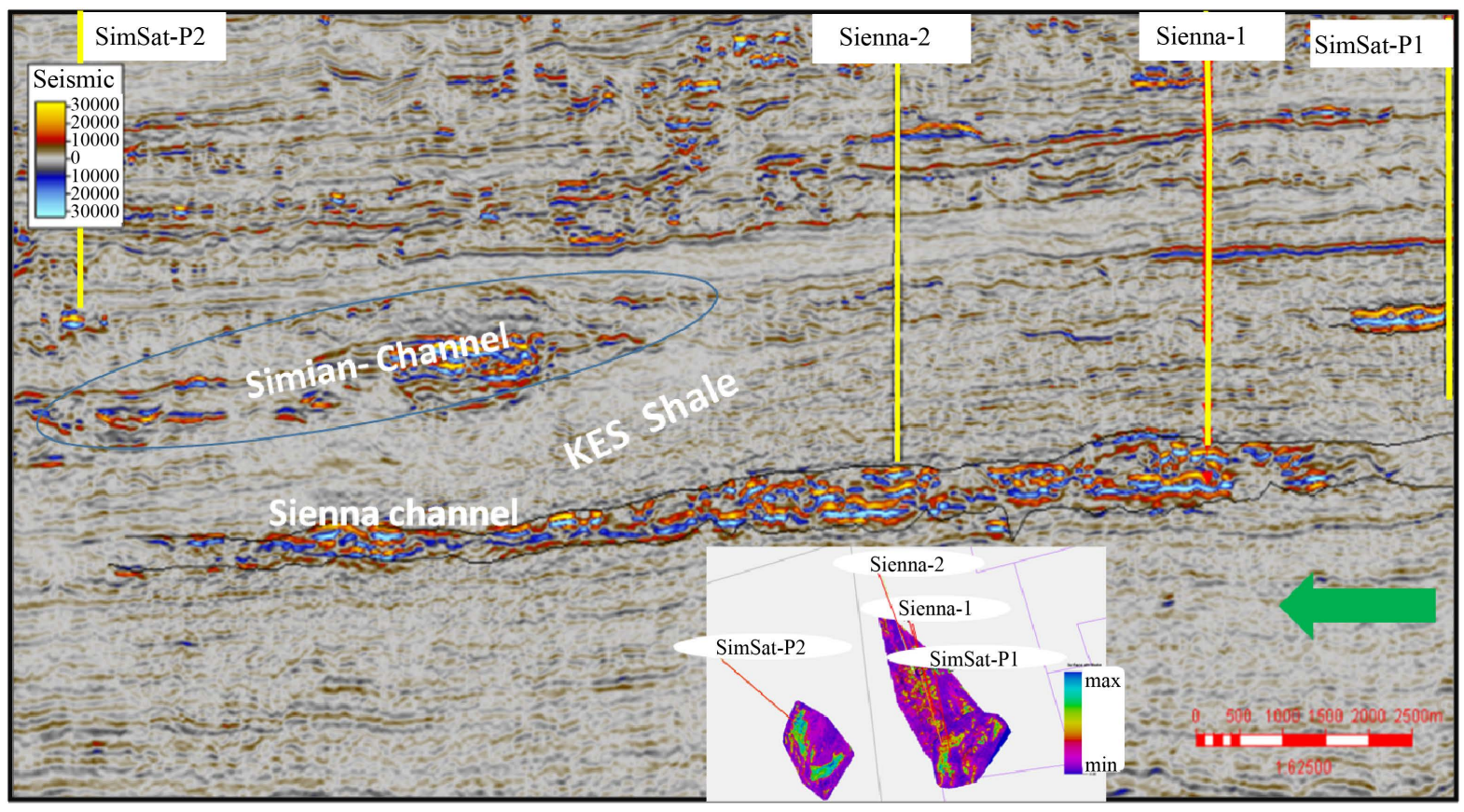

Figure 2. Arbitrary Seismic Section across the studied reservoir targets showing their intervals relative to each other. 


\section{Geological Setting and Stratigraphic Framework}

The geologic evolution of the Nile Delta (Figure 3) can be traced back to the Late Eocene-Oligocene time [11][13]. Recent exploration activities focused on Plio-Pleistocene sequences where the main gas reservoirs are encountered.

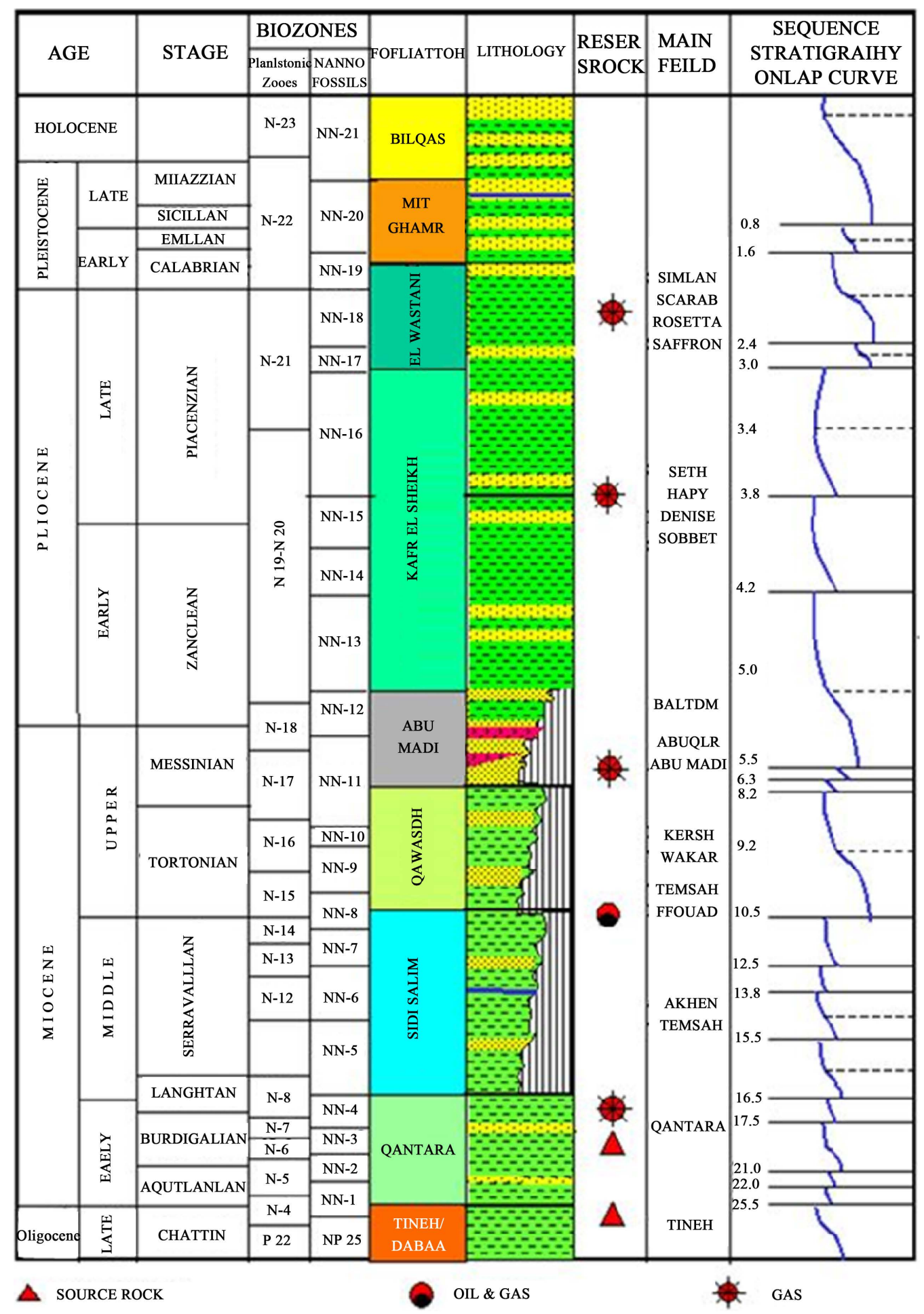

Figure 3. Generalized lithostartigraphic column of the West Delta Deep Marine (WDDM) field (Raslan, 2002). 
The structural configuration of the western side of the offshore Nile Delta is dominated by a major NE-SW striking/NW down throwing normal fault. Seismic interpretation indicates that the maximum throw reaches around 900 ms. This fault throw decreases northward and eventually dies out against a series of NW-SE striking faults. Thickness of the Pliocene-Pleistocene succession remains considerable even in the northern part of the concession. The present slope has a gradient of around 1:25. Regional seismic profiles reveal presence of large scale clinoforms and shelf-slope break. Seismic profiles show that the shelf-slope break was migrated northward with time and evidence of back stepping phases.

The major structural feature within the concession is the SW-NE-trending Nile Delta Offshore Anticline (NDOA). It has been active at various periods during the Pliocene and Pleistocene (Figure 4). Absence of significant thickening of Plio-Pleistocene sequences in the seismic sections indicates that the NDOA did not have a major impact on the depositional geometries [8].

Early to Late Pliocene is represented by the Kafr El Sheikh Formation. It started with the deposition of the Early Pliocene sediment during marine flooding. This Formation is incised at the top by low-stand and progradingclastics of the Plio-Pleistocene age (El Wastani Formation). The old paleogeography and tectonic elements play an important role in the thinning of the formation onshore. The paleobathymetry of the Kafr El Sheikh indicates an inner to middle tides and it goes outer and upper bathyal northward.

Late Pliocene to Early Pleistocene is represented by El Wastani Formation. It forms a regressive sequence that unconformably overlies the Kafr El Sheikh Formation. The depth of El Wastani Formation ranges from $900 \mathrm{~m}$

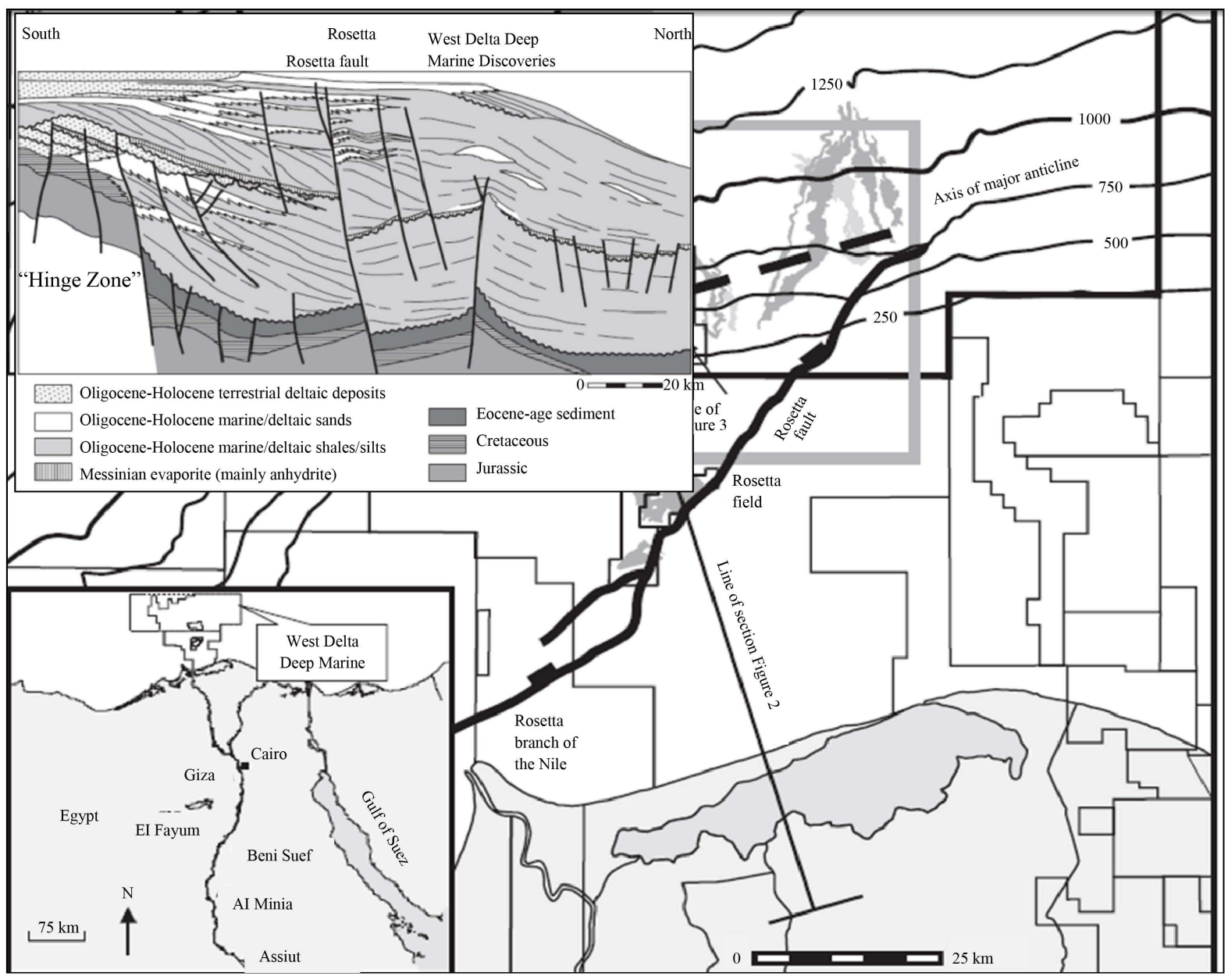

Figure 4. Major structural features within the Wes Delta Deep Marine (WDDM) concession. Water depth is given in meters. The limit of the West Delta Deep Marine Concession is highlighted in bold. The upper Pliocene discoveries are shaded gray. The line of the schematic cross section (inset figure). The inset figure represents Schematic cross section modified after [14], (modified after [8]). 
to $1000 \mathrm{~m}$. The thickness appears to be controlled by the Rosetta fault that was active in the top of the Kafr ElSheikh Formation due to the dipping of the formation to the NW and SW.

El Wastani Formation was deposited as low-stands channels extending towards the north in Scarab and Saffron areas. It reflects fan deposits and overbanks on some areas. The paleobathymetry of El Wastani Formation shows a shallow marine, inner to middle neritic southward that changes to outer to upper bathyal in the north.

Pleistocene to Holocene is represented by the MitGhamr and the Bilqas Formations. The MitGhamr Formation was recorded as $464 \mathrm{~m}$ thick in the MitGhamr well\#1 [13]. It consists of thick layers of sand and pebbles at its base with clay and carbonaceous interbeds of limited thickness. This Formation grades in facies to interbedded sand with clay. The sand is rich in peat, coastal and lagoon fauna. It constitutes a fill-up of the top basin with shelly sands, coquina beds, clays and peat and deposits from the Nile flood. The depositional environment of this formation is probably shallow marine to fluvial environment.

The Bilqas Formation covers the whole Nile Delta area with type section of $25 \mathrm{~m}$ at the Bilqas well\#1. It is composed of interbedded sand with clay and is rich in molluscan fragments. The clay beds contain plant remains and carbonaceous debris mixed with windblown sand. The faunal association reflects a lagoon, brackish swamp, environment interrupted by beach sand [15].

The studied wells penetrated a stratigraphic sequence extends from Pleistocene to Pliocene. The rock unit boundaries are identified based on foraminiferal and Nannoplanktonic analyses. The stratigraphic analysis of the studied wells is illustrated in Table 1.

\section{Methodology}

The SimSat-P1, SimSat-P2, Sienna-1 \& Sienna-2 reservoirs were covered by 3D surveys in 1998, 2003 and 2006. Seismic features and attributes were identified and subsequently worked up by using the 2006 survey. For

Table 1. Stratigraphic summary of the studied wells.

\begin{tabular}{|c|c|c|c|c|c|c|c|c|c|}
\hline \multirow{3}{*}{ Well Name } & \multirow{3}{*}{ Age } & \multirow{3}{*}{ Formation } & \multirow{3}{*}{$\begin{array}{l}\text { Water } \\
\text { Depth } \\
\text { (MD) }\end{array}$} & \multirow{3}{*}{$\begin{array}{l}\text { Total } \\
\text { Depth } \\
\text { (MD) }\end{array}$} & \multirow{2}{*}{\multicolumn{3}{|c|}{$\begin{array}{r}\text { Biostratigraphic Summary } \\
\text { Interval (MD) }\end{array}$}} & \multicolumn{2}{|c|}{ Litho Stratigraphic Summary } \\
\hline & & & & & & & & \multirow{2}{*}{ Marker } & \multirow{2}{*}{ MD } \\
\hline & & & & & Biozones & From & To & & \\
\hline \multirow{4}{*}{ Sienna-1 } & \multirow{4}{*}{ Pliocene } & \multirow{4}{*}{$\begin{array}{c}\text { Kafr El } \\
\text { Sheikh FM }\end{array}$} & \multirow{4}{*}{$944.0 \mathrm{~m}$} & \multirow{4}{*}{$2575 \mathrm{~m}$} & NN19a & 1510 & 2190 & Top Sienna Channel & 2372 \\
\hline & & & & & NN18 & 2190 & 2230 & Base Sienna Channel & 2475.2 \\
\hline & & & & & NN17 & 2230 & 2290 & $\begin{array}{c}\text { Top Sienna Basal } \\
\text { Slumps }\end{array}$ & 2475.2 \\
\hline & & & & & NN16a & 2290 & 2574 & $\begin{array}{c}\text { Base Sienna Basal } \\
\text { Slumps }\end{array}$ & 2520 \\
\hline \multirow{3}{*}{ Sienna-2 } & \multirow{3}{*}{ Pliocene } & \multirow{3}{*}{$\begin{array}{c}\text { Kafr El } \\
\text { Sheikh FM }\end{array}$} & \multirow{3}{*}{$1012.00 \mathrm{~m}$} & \multirow{3}{*}{$2600 \mathrm{~m}$} & NN19a & 1540 & 2050 & $\begin{array}{c}\text { Top of Sienna main } \\
\text { Channel }\end{array}$ & 2417 \\
\hline & & & & & NN17/18 & 2050 & 2250 & Top of Basal Slumps & 2501.8 \\
\hline & & & & & NN16a & 2250 & 2600 & Base of Sienna Canyon & 2540.6 \\
\hline \multirow{7}{*}{ SimSat-P1 } & \multirow{7}{*}{$\begin{array}{c}\text { Late } \\
\text { Pliocene }\end{array}$} & \multirow{7}{*}{$\begin{array}{l}\text { El Wastany } \\
\text { FM }\end{array}$} & \multirow{7}{*}{$891.00 \mathrm{~m}$} & \multirow{7}{*}{$2230 \mathrm{~m}$} & NN19f & 891 & 1470 & Top Reservoir & 2121 \\
\hline & & & & & NN19e & 1470 & 1740 & Base Reservoir & 2160 \\
\hline & & & & & NN19d & 1740 & 1860 & & \\
\hline & & & & & NN19c & 1860 & 2045 & & \\
\hline & & & & & NN19b & 2045 & 2120 & & \\
\hline & & & & & NN19a & 2120 & 2185 & & \\
\hline & & & & & NN18 & 2220 & 2230 & & \\
\hline \multirow{3}{*}{ SimSat-P2 } & \multirow{3}{*}{$\begin{array}{c}\text { Late } \\
\text { Pliocene }\end{array}$} & \multirow{3}{*}{$\begin{array}{c}\text { El Wastany } \\
\text { FM }\end{array}$} & \multirow{3}{*}{$994 \mathrm{~m}$} & \multirow{3}{*}{$1998 \mathrm{~m}$} & NN19f & 1520 & 1550 & Top Reservoir & 1904 \\
\hline & & & & & NN19e & 1550 & 1670 & Base Reservoir & 1918 \\
\hline & & & & & NN19d & 1670 & 1998 & & \\
\hline
\end{tabular}


all of the seismic surveys, gas-bearing reservoirs in the Pliocene have soft kicks corresponding to peaks as tops. The bases are marked by hard kicks or troughs. The standard color convention which isused to present all seismic data is a cyan marker on blue to represent a peak (soft kick) and a yellow marker on red to represent a trough (hard kick).

The interpretation of the reprocessed seismic data indicates that the upper most Plio-Pleistocene sequence consists of broadly parallel and continuous reflector that was produced by prograding oblique/complex clinoforms of deep marine shale. This shale represents the major delta outbuilding phase. Formation micro imaging (FMI) was used as a main tool for lithology and sedimentary structure interpretation. The interpreted lithologies were grouped into lithofacies associations that are directly related to certain depositional environments. The FMI have added fine scale details such as vertical facies variations and stratigraphic dip changes, which are both crucial for defining the main lithofacies paleo-slope and paleo-current orientations. FMI tool also provided strong clues for identification of key depositional surfaces.

\section{Sedimentological Interpretation}

Detailed sedimentological interpretation was performed over the study area by using FMI along the drilled wells, core data and seismic attributes. The main objectives are to describe lithofacies and determine the depositional environment based on the interpreted sedimentary structures.

The following is a description of each field and the type of channel features existed:

\subsection{SimSat-P1 Reservoir}

SimSat-P1 reservoir is represented seismically by thin parallel bright reflector. SimSat-P1 reservoir is shallower than the deeper Simian channel trend. The reservoir was penetrated by SimSat-P1 well that was drilled as a vertical hole to a total depth of $2230 \mathrm{~m} \mathrm{MD} \mathrm{(-2208} \mathrm{m} \mathrm{TVDss).} \mathrm{The} \mathrm{top} \mathrm{SimSat-P1} \mathrm{reservoir} \mathrm{is} \mathrm{seismically} \mathrm{picked}$ at $-2328.55 \mathrm{~ms}$ and the base at $-2379.82 \mathrm{~ms}$ which is equivalent to $2121 \mathrm{~m} \mathrm{MD}$ ( -2098.7 TVDss) for the top and $2160 \mathrm{~m} \mathrm{MD} \mathrm{(-2137.7} \mathrm{m} \mathrm{TVDss)} \mathrm{for} \mathrm{the} \mathrm{base.} \mathrm{The} \mathrm{reservoir,} \mathrm{at} \mathrm{well} \mathrm{location,} \mathrm{consists} \mathrm{of} 39 \mathrm{~m}$ of successive argillaceous sandstones (sheet-like), interbedded with claystone and siltstone.

Biostratigraphic analysis of the SimSat-PI well indicates that the reservoir is of Late Pliocene-Pleistocene age. The Pliocene sequence is represented by NN19a and NN18. The topmost part of the seismic profile represents the upper most Plio-Pleistocene sequence. Depth converted maps of both top and base SimSat-P1 reservoir by using 2003 Average velocity cube indicate the reservoir is dipping toward NW direction. Generated isopach map (Figure 5) indicates that SimSat-P1 reservoir thickness varies from 15 m - 55 m with the maximum thickness in the western part of the reservoir around SimSat-P1 well. Attribute map of SimSat-P1 reservoir shows that it extends to approximately $16.5 \mathrm{~km}^{2}$ area and is oriented to NE-SW direction with an average thickness of 39 m (Figure 5).

Facies analysis of the SimSat-P1 well based on wire line logs and FMI resulted in number of units with different characteristics indicating various depositional features (Figure 6). The facies are:

\subsubsection{Pre-Fan Background}

This interval extends from depth $2201.0 \mathrm{~m}$ to $2159.9 \mathrm{~m}$ in SimSat-P1 well with an average thickness of $41 \mathrm{~m}$. The facies is striking ESE-WNW and is characterized by dominance of laminated mudstone that grades to silt, with few carbonate and small pyrite nodules. Some silt intervals are defined by FMI and are characterized by steep dip and chaotic azimuths. The contact of the top most part of this facies and the overlying sand unit is an erosional event marked by dewatering deformational structure. FMI analysis also shows that this mud succession is punctuated with two cohesive shale debris flow intervals with chaotic internal fabric, and floating clasts. The mudstone-shale facies is most probably accumulated as a pre-fan background pelagic to hemi-pelagic mud deposited from suspension fall out. The siltstone-rich intervals have many deformational features most probably due to dewatering process. The base of the onset of the overlying unconfined sand sheets is marked by a sharp lithologic contact.

\subsubsection{Distal Mid Fan Sheet Sand}

This facies association extends from depth $2126.7 \mathrm{~m}$ to $2159.9 \mathrm{~m}$ with thickness around $33 \mathrm{~m}$. It is characterized by very low dip reflector that is consistently propagating to the NE. It consists of amalgamated and stacked sand 

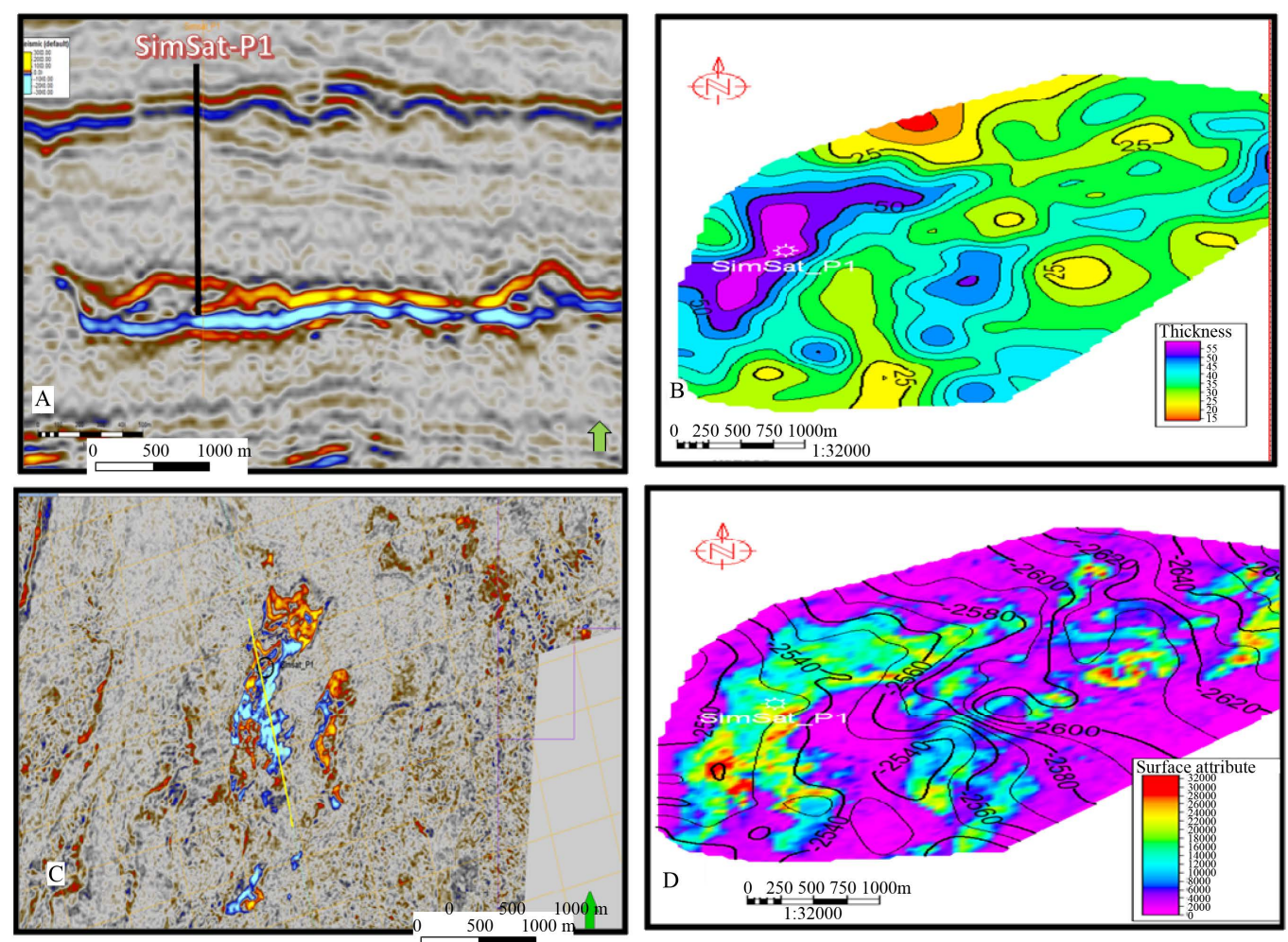

Figure 5. SimSat-P1 reservoir. (A) Seismic section at SimSat-P1 location; (B) Isochore map for SimSat-P1 picked horizons; (C) Horizontal time slice over SimSat-P1 area and (D) Extracted Maximum Magnitude Attribute map.

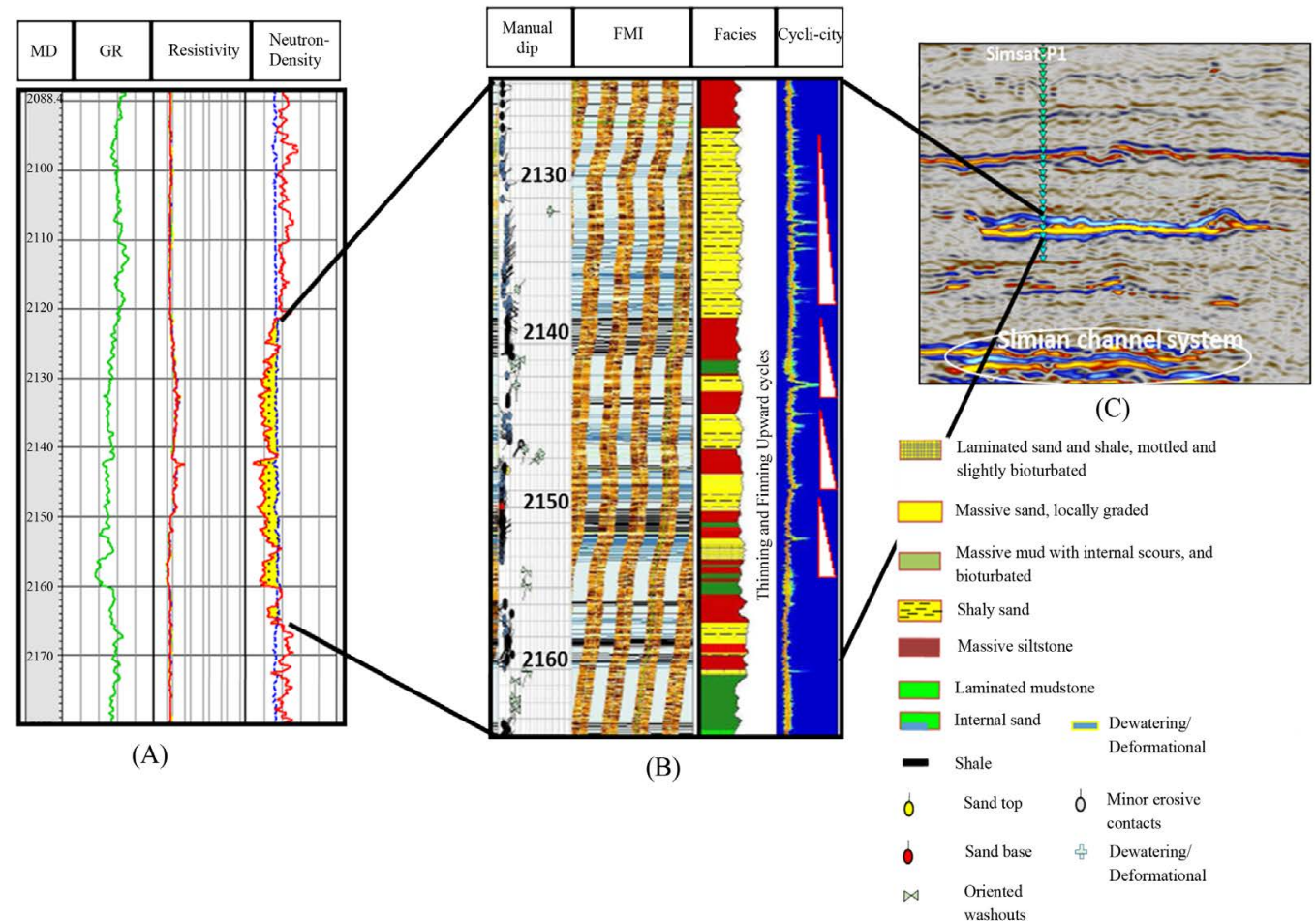

Figure 6. Summary of vertical facies described from SimSat-P1 well. (A) Depositional facies calibrated to neutron density log along the well; (B) Facies described from FMI with predicted lithology and related fining upward cycles; (C) Seismic profile across SimSat-P1. 
sheets with frequent clay lenses. These amalgamated sand sheets are deposited punctuated by mud. The flat, bedded sand with parallel bases and tops form unconfined sheet sand unit. Seismic and FMI data indicate unconfined sheet sand deposition.

\subsubsection{Post Fan Background Mud}

This unit consists of massive pelagic to hemi-pelagic shale with unrecognizable sedimentological features. It is occasionally silty, especially towards the top. FMI analysis shows that there is a minor deformational structure within the silt interval, most probably due to bottom current reworking and dewatering. This entirely muddominated unit was most probably deposited from suspension and may represent post-fan background mud deposition i.e. non-turbiditic shale. Many shale intervals are washed-out with E-W trend pointing to the actual horizontal minimum stress. This facies association is most probably related to maximum sea-level rise and designate transgressive systems tract TST of the third order sequence [16] (Figure 6).

The SimSat-P1 reservoir intervals were subdivided into different zones based on rock properties. The petrophysical analysis of the processed zones can be summarized as follows (Table 2).

\subsection{SimSat-P2 Reservoir}

The top SimSat-P2 reservoir was picked at $1904 \mathrm{~m} \mathrm{MD} \mathrm{(-1879.69} \mathrm{m} \mathrm{TVDss),} \mathrm{equivalent} \mathrm{to}-2628.98 \mathrm{~ms}$ on seismic. The reservoir base was picked at1918 m MD (-1893.7 m TVDss) equivalent to -2687.69 ms on seismic. The structural mapping was done based on 3D seismic survey in 2006. Structure maps based on average velocity cube for both top and base SimSat-P2 reservoir show dipping toward NW direction. The reservoir thickness varies from $18 \mathrm{~m}$ to $57 \mathrm{~m}$. Maximum thickness is around the SimSat-P2 well location.

The reservoir is subdivided based on maximum magnitude amplitude between the top and the base of the reservoir into two main parts. The two parts are, one to the west, oriented to NW-SE, and of approximately $1805.25 \mathrm{~m}$ length and $450.7 \mathrm{~m}$ width. The other part is to the east, oriented to NE-SW direction, and of approximately $2920.37 \mathrm{~m}$ length and $874.76 \mathrm{~m}$ width (Figure 7).

Facies analysis of the SimSat-P2 well based on wire line logs and FMI resulted in number of units with different characteristics indicating various depositional features (Figure 8). The depositional facies are:

\subsubsection{Channel Base}

This interval extends from depth $1985 \mathrm{~m}$ to $1972 \mathrm{~m}$ and is represented by massive shale and silt with rare laminations. It is marked at the top by a sharp erosive surface which may probably stands for a channel base.

\subsubsection{Inner Fan Slump}

This interval consists mainly of 15 m thick (1972 m - $1917.8 \mathrm{~m}$ ) of massive and laminated shale grades to siltstone and sandstone. The sandstone is mainly fine to medium size with a maximum thickness of $0.5 \mathrm{~m}$ and forms isolated bodies that might have been deposited as gullies. The interval is characterized by predominance of slumped mud and scoured surfaces as interpreted from the FMI. FMI analysis also shows steep dip and chaotic azimuths indicative for probable dewatering and deformational structures. Mud succession is truncated by three cohesive debris flow intervals with chaotic internal fabric, and floating clasts. These features represent possible inner-fan slumps regime deposited from diluted turbiditic flows that were responsible for depositing these small isolated (gully-scale) sand units [17]. FMI analysis indicates also that, all scour surfaces that mark the base of these gullies are high in dip magnitude $\left(\sim 30^{\circ}\right)$, which most probably defines a relatively high energetic flow that cut into the shale beds. This unit might have been deposited as inner fan (passive channel deposi

Table 2. Summary of petrophysical analysis of SimSat-P1 final well report.

\begin{tabular}{ccccccccccccccc}
\hline Zone Name & Top & Bottom & Thickness & Net Pay & NTG & Vsh & $\varphi($ Phi $)$ & Phi $\times$ h & Sw & HPV $\times$ h \\
\hline Fan mud & 2121.32 & 2129 & 7.68 & 0 & 0 & 0 & 0 & 0 & 0 \\
Sheet Sand & 2129 & 2150 & 21 & 13.89 & 0.66 & 0.41 & 0.21 & 2.91 & 0.57 & 1.24 \\
Shaly Sand & 2150 & 2160.2 & 10.2 & 0.03 & 0 & 0.34 & 25 & 0.01 & 0.69 & 0 \\
Total & -- & -- & 38.88 & 13.92 & 0.66 & 0.39 & 23 & 2.92 & 0.63 & 1.24 \\
\hline
\end{tabular}



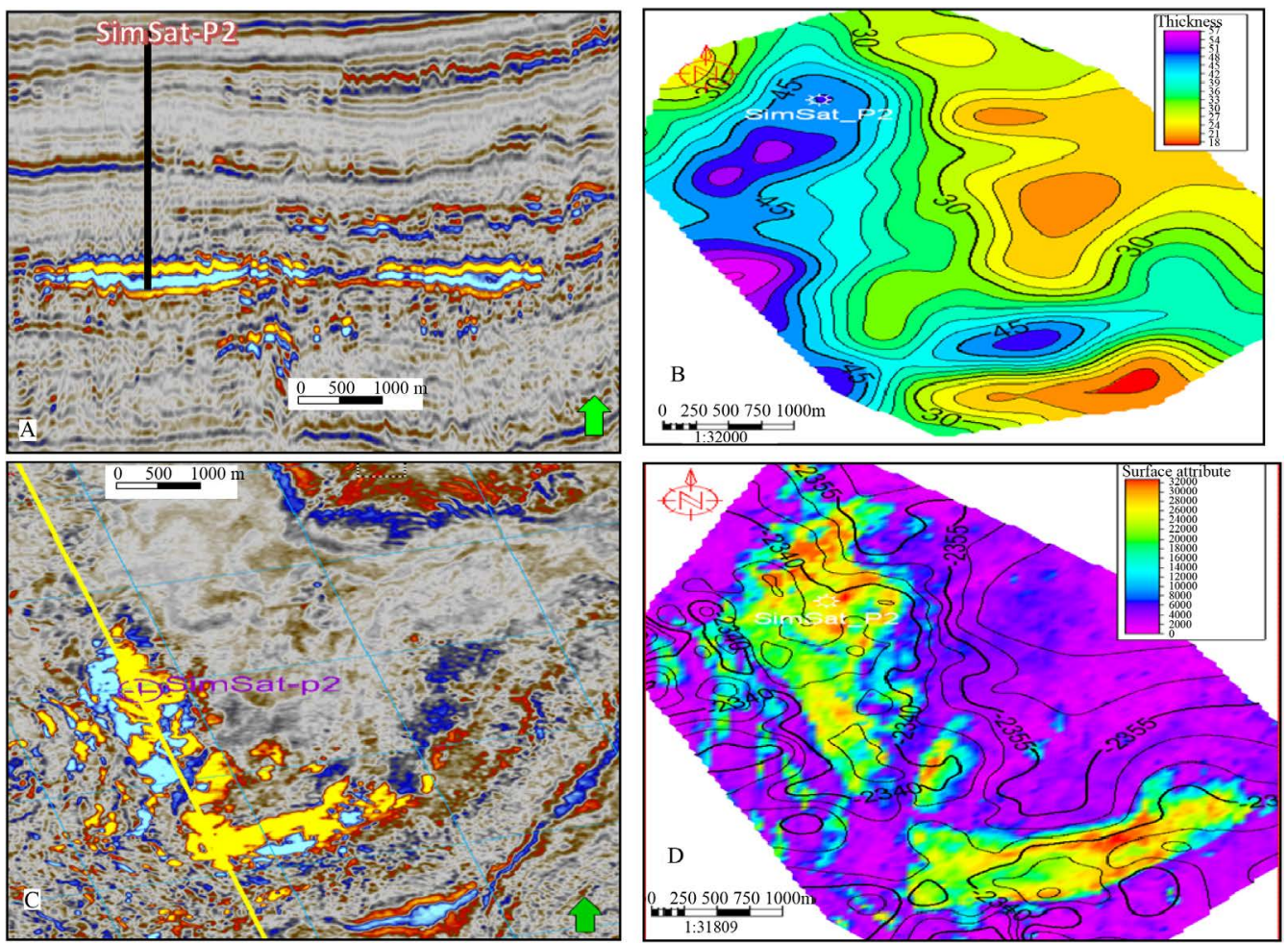

Figure 7. Seismic interpretation of SimSat-P2 Reservoir. (A) Cross line sections through the high amplitude area in SimSat-P2 reservoir showing laterally extended two high quality segments (bright) separated by mudstone (dim); (B) Thickness map for the picked SimSat-P2 horizons; (C) Horizontal time slice across the reservoir; (D) Maximum magnitude attribute between the top and the base of the picked horizons.

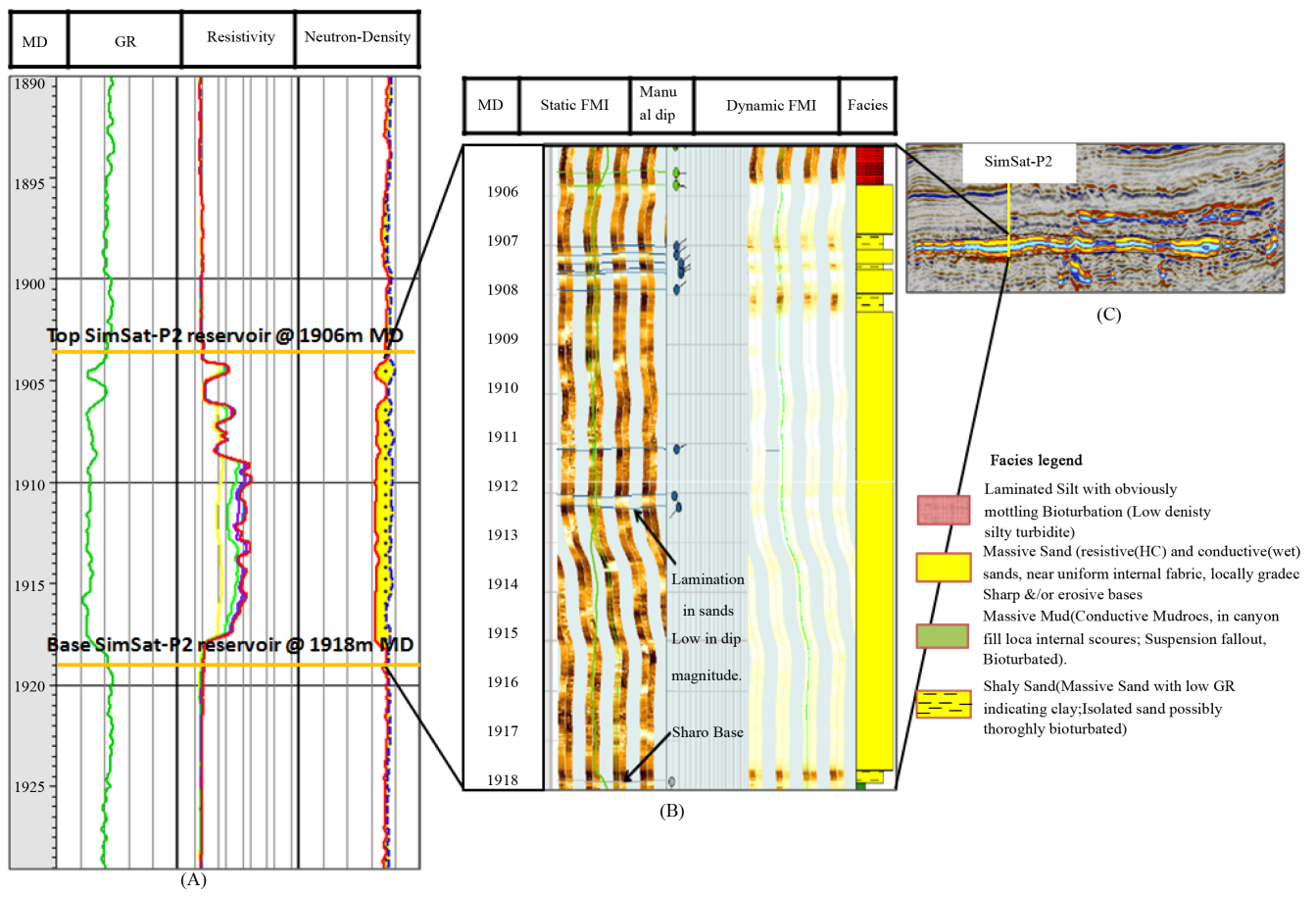

Figure 8. Summary of vertical facies described from SimSat-P1 well. (A) Depositional facies calibrated to neutron density log along the well; (B) Facies described from FMI with predicted lithology and related fining upward cycles; (C) Seismic profile across SimSat-P1 well showing lateral reservoir extension east of the well area. 
tion) which is defined by presence of inner-fan characteristics such as slumps, gully sands and scouring with no remarkable turbiditic event. The base of the onset of the overlying unconfined sheet sands is marked by a sharp lithologic contact.

\subsubsection{Proximal Mid Fan Sheet Sand}

This facies is described from $1917.8 \mathrm{~m}$ to $1903.5 \mathrm{~m}$ and is characterized by dominance of sand lithology. The sand is mainly fine to locally medium size. FMI analysis of this facies is dominated by stacked sand sheets with locally occurred clays lenses (most probably flaser bedding) and internal laminations. Deformation (dewatering) is not evident. Seismic data shows flat bedded sands with parallel bases and tops suggestive for unconfined sheet sands.

FMI analysis shows that the basal part of this succession is characterized by presence of sharp lithologic contact which may be an evidence for reactivation surface with low dip magnitude nature. This high density to diluted turbiditic unconfined flow is mostly shale sandstones. FMI analysis indicates also that these amalgamated sand sheets are characterized by very low dip magnitude and consistently propagating to the NE. The sand unit is massive at the base and contains some shale lenses at the top. The unit is characterized by a fining upward succession defining the transition from proximal to distal mid-fan deposits. This association is interpreted as low stand system tract (LST) of third order magnitude [16].

\subsubsection{Distal Mid Fan Mud}

This facies (1903.5 m - $1895 \mathrm{~m}$ ) is characterized by 8m thick of thin laminated silt with few slumped shale beds and minor erosive intervals of low-density turbiditic flow. This unit is interpreted as having been deposited within the mid-fan setting at the proximal part, more distal than the unit above.

\subsubsection{Post Fan Background Mud}

This interval consists of $95 \mathrm{~m}$ of shale, mudstone and siltstone beds. It extends from depth $1895.0 \mathrm{~m}$ to $1800.0 \mathrm{~m}$. The interval is occasionally silty towards the top. Minor deformational features were described form these siltsdominated beds. These features are most likely to indicate bottom current reworking and dewatering. Many shale intervals are washed-out. This unit represents a flooding surface that was deposited from suspension. Based on the regional depositional setting of the area, it most probably represents post-fan background mud deposition due to maximum sea-level rise.

Petrophysical analysis for the processed interval in SimSat-P2 well can be summarized as follows (Table 3).

\subsection{Sienna Reservoir}

Sienna reservoir is one of the major channel systems that make up the mid-Pliocene submarine channel complex. Sienna forms a combined stratigraphic/structural trap with updip (southern) fault closure. Down dip, the reservoir is a combined dip and stratigraphic closure along the length of the channel. The reservoir pinches out at both eastern and western channels margins. The seal is the Kafr El Sheikh Formation claystone of the Late Pliocene age.

Sienna channel complex commenced deposition in the Late Pliocene as indicated form high resolution biostratigraphic analysis carried out on Sienna-1 and Sienna-2 wells [18]. The channel complex occupies an area around $54.68 \mathrm{~km}^{2}$. It consists of $123 \mathrm{~m}$ thick of thin shale, interbedded with siltstones, claystones, and thick coarse sandstone beds.

Core description of Sienna-2 well indicates that the reservoir is characterized by interbedded fine grained

Table 3. Petrophysical analysis of SimSat-P2 well.

\begin{tabular}{|c|c|c|c|c|c|c|c|c|c|c|}
\hline Zone Name & Top & Bottom & Thickness & Net Pay & NTG & Vsh & $\varphi$ (Phi) & Phi $\times h$ & Sw & $\mathrm{HPV} \times \mathrm{h}$ \\
\hline Fan Mud & 1860 & 1904 & 7.68 & 0 & 0 & 0 & 0 & 0 & 0 & 0 \\
\hline $\begin{array}{l}\text { Reservoir } \\
\text { Sandstone }\end{array}$ & 1904 & 1918 & 14 & 12.65 & 0.9 & 0.05 & 0.32 & 4.06 & 0.19 & 3.31 \\
\hline Bottom Shale & 1918 & 1965 & 47 & 0.3 & 0.01 & 0.35 & 0.23 & 0.07 & 0.69 & 0.02 \\
\hline Total Interval & 1860 & 1965 & 105 & 12.95 & 0.12 & 0.06 & 0.32 & 4.13 & 0.19 & 3.33 \\
\hline
\end{tabular}


sandstones and siltstones with shale. Few intervals show micro faults, ripple cross laminations and evidences of sliding and soft sediment deformation such as convolute bedding (Figure 9).

Generated Maximum Magnitude Attribute map between the top and the base reservoir shows that Sienna channel system is broadly oriented north-south. Numerous, meandering channels are concentrated within the main branch. The Sienna channel trend is mainly NNW-SSE and consists of two main branches to the east and the west. The main meandered channel branch trend is NW-SE direction with approximately $16.88 \mathrm{~km}$ length. The channel width varies from $1.064 \mathrm{~km}$ at Sienna-2 well location to $1.13 \mathrm{~km}$ at Sienna-1 well location. The minimum width is approximately $476 \mathrm{~m}$ (Figure 10).

Sienna channel complex was penetrated by Sienna-1 and Sienna-2 wells in the deep water (250 - $1500 \mathrm{~m})$.
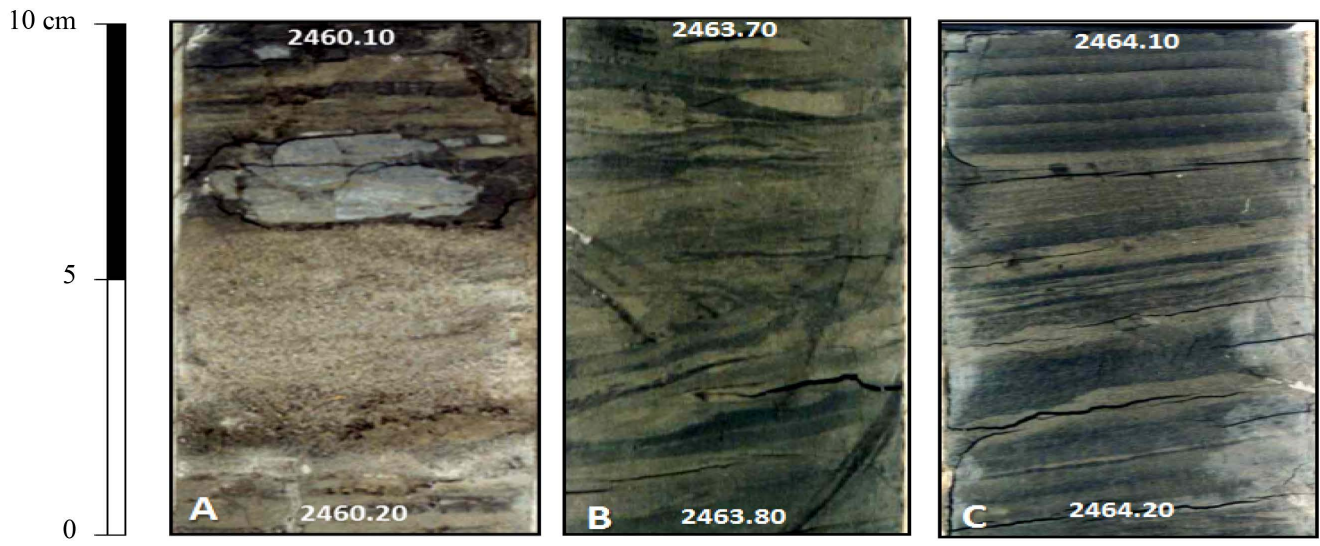

Figure 9. Examples of sedimentary facies described from Sienna-2. (A) Massive, fine grained sandstone overlain and underlain by thick shale; (B) Interbedded siltstones and mudstones with slumped facies due to soft-sediment deformation; (C) Thin-to medium-bedded sandstone, and mudstone facies. This sandstone is generally parallel and ripple cross-laminations in the finer grained material.
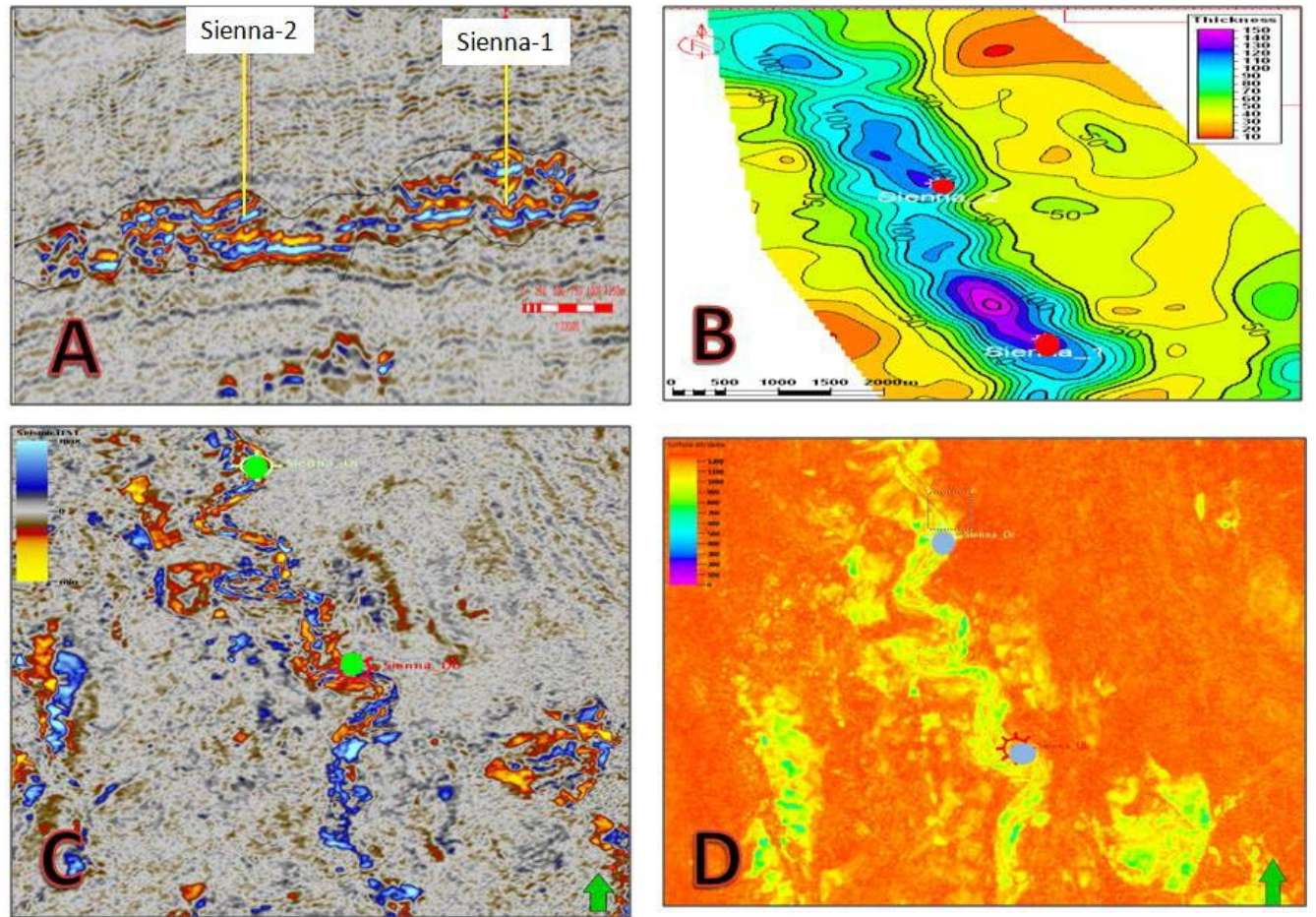

Figure 10. Sienna reservoir. (A) Cross line sections through the high amplitude area in sienna reservoir passing through Sienna-1 well and Sienna-2 well; (B) Thickness map for the picked Sienna horizons; (C) Horizontal time slice; (D) RMS attribute between top and base picked horizons. 
The major tectonic controls on the area are the SW/NE Rosetta fault trend and the ENE-WSW NDOA anticline trend. Sienna-1 was drilled as vertical borehole, with a TD of 2575 m MD (-2551.5 m TVDss). It penetrated successfully $103 \mathrm{~m}$ of gas bearing Sienna channel unit.

The spatial distribution of seismic amplitude over the Sienna reservoir was interpreted by using a horizontal time slice, generated over interval with $10 \mathrm{~ms}$ time increment (Figure 11).

Petrophysical evaluation for all reservoir intervals which are indicated as pay based on conventional logs can be summarized as follows (Figure 12, Table 4).

\section{Depositional Scenario and Reservoir Architecture}

The depositional setting of the Plio-Pliestocene, Wastani Formation, is largely controlled by both relative sea level changes and slope generated by major structural trends (Rosetta and NDOA). The channel evolution through time is not very clearly defined due to the lack of drilled wells, cores and stratigraphic heterogeneities of the reservoirs. High resolution seismic coverage of the Simian-Sienna lease along with FMI data of the available wells provide an excellent opportunity to understand the depositional evolution, reservoir architectures and sand body geometries. The channel architectures and evolution stages are not different from those described nearby fields within WDDM concession such as Scarab [8] and Sequoia fields [19].

Seismic cross sections across the study area indicate that the sandstone units are characterized by unconstrained sheet-like sandstone and siltstone beds referring most probably to a fan (lobe) deposition. The flatbedded sand facies is most probably supportive of a more distal, possibly mid-fan setting. Seismic cross sections and FMI show variable types of unconfined and confined channels complexes across the study area. The channels are either single story that refer to a short lived progradational event or multi-story that refer to successive aggradational process. Seismic maximum attribute maps show that laterally amalgamated sinusoid channels are the main channel feature within the unconfined type.

Sienna channel complex is stratigraphically the oldest channel complex in Simian/Sienna development lease. Seismic time slices indicate that Sienna channel complex consists of unconfined channel system with clearly defined evolution stages (Figure 13).

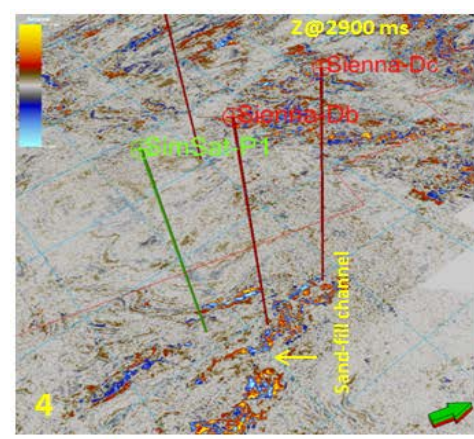

4) Laterally progradtional amalgamated channels

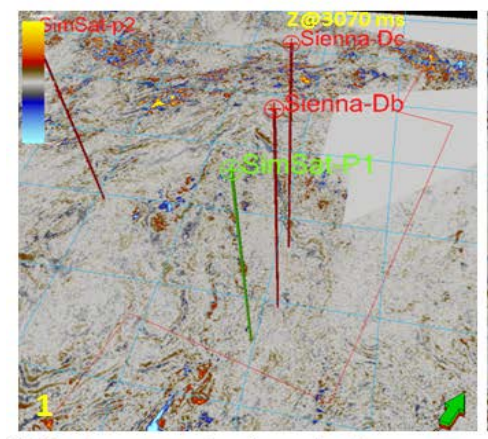

1) Abandonment and maximum flooding

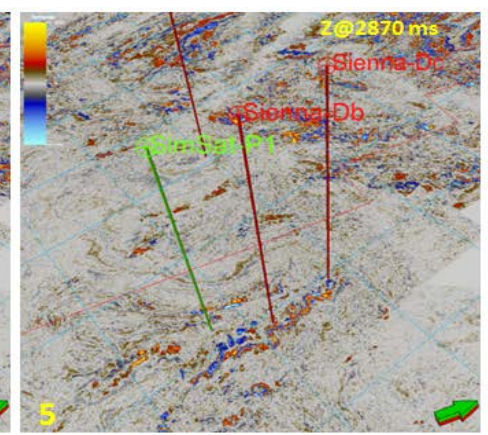

5) Aggradational and sinus channels

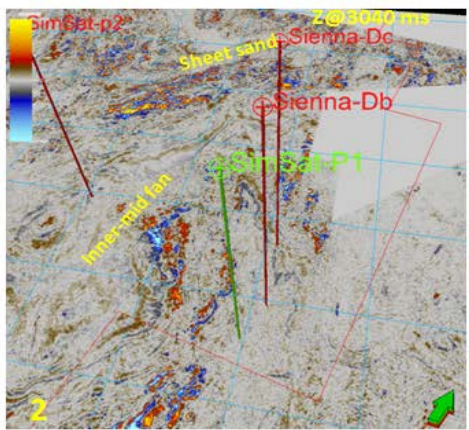

2-3)Last

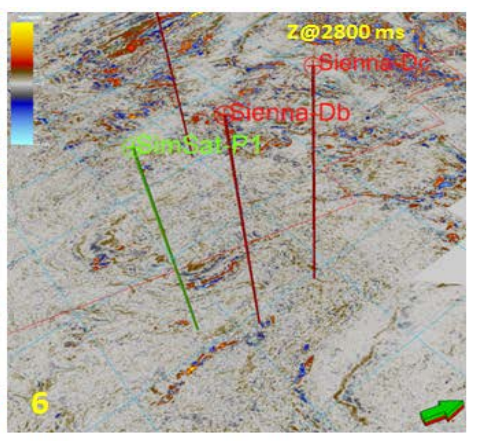

6) Abandonment and flooding

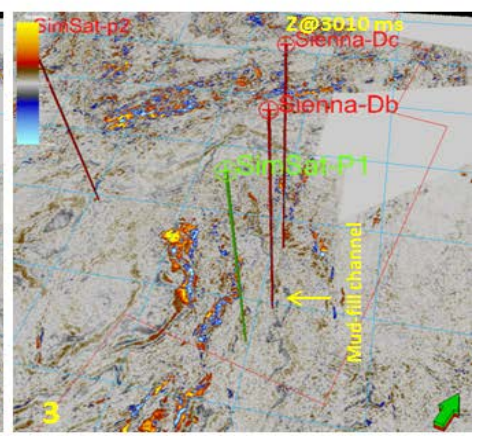

Laterally progradtional channels with fan deposition at the west and mud-fill channel at the

Figure 11. Series of time seismic time slices showing, in ascending order, the depositional evolution of the Sienna channel system. 

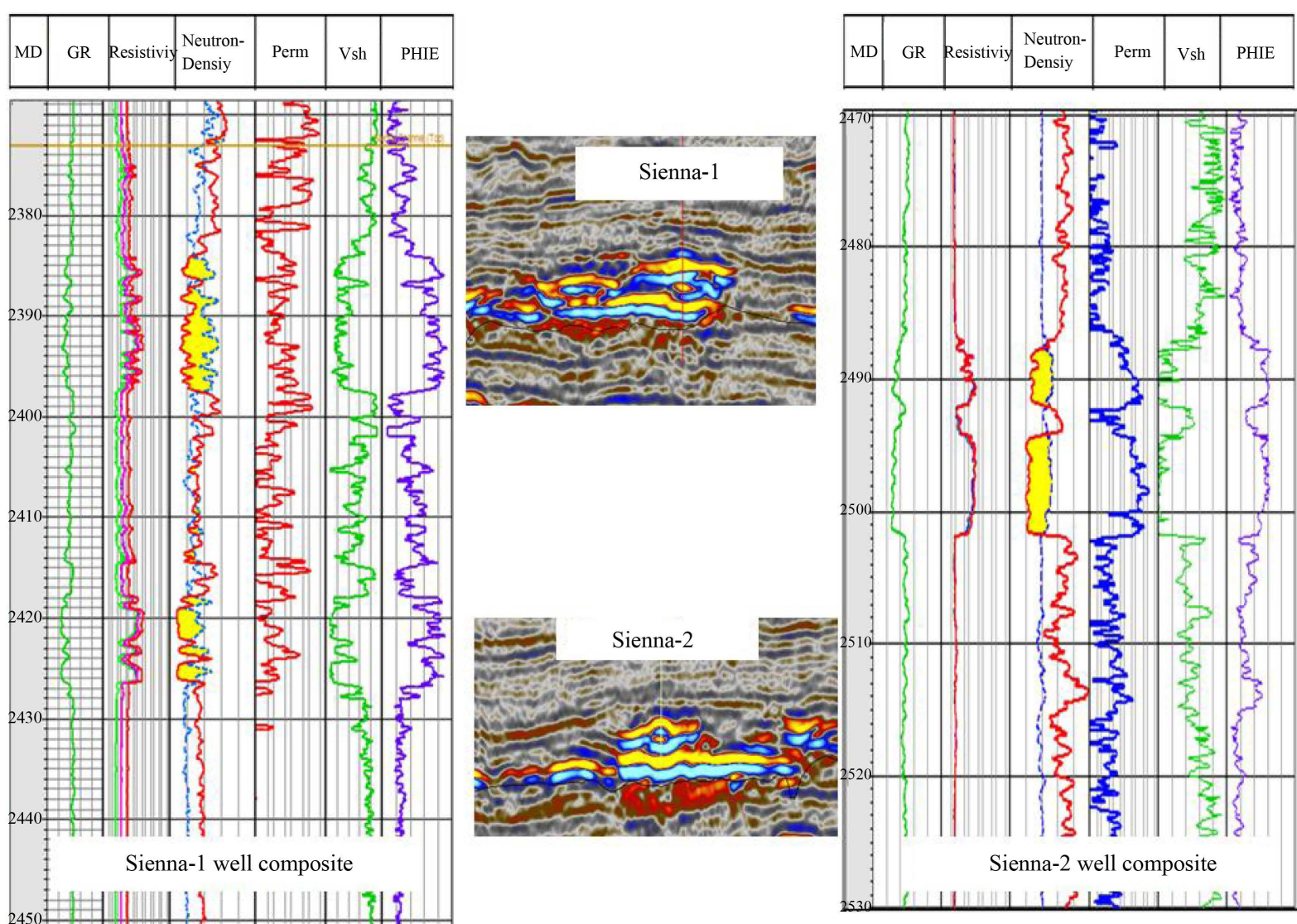

Figure 12. Composite logs for both Sienna-1 well and Sienna-2 well with displaying seismic line through each well.

Table 4. Summary of petrophysical analysis for Sienna-1 well and Sienna-2 well.

\begin{tabular}{cccccccccccc}
\hline $\begin{array}{c}\text { Well } \\
\text { Name }\end{array}$ & Zone Name & Top & Bottom & Thickness & Net Pay & NTG & Vsh & $\varphi($ Phi $)$ & Phi $\times \mathrm{h}$ & Sw & HPV $\times \mathrm{h}$ \\
\hline \multirow{5}{*}{ Sienna-1 } & $\begin{array}{c}\text { Core Sand } \\
\text { Interbeds (Slumps, } \\
\text { corecheoics) }\end{array}$ & 2379.5 & 2398 & 18.5 & 13.82 & 0.747 & 0.263 & 0.3 & 4.139 & 0.196 & 3.327 \\
& Core Sand & 2418 & 2428 & 10 & 9.46 & 0.947 & 0.161 & 0.277 & 2.625 & 0.19 & 2.127 \\
& TOTAL & 2379.5 & 2428 & 48.5 & 11.52 & 0.237 & 0.31 & 0.26 & 2.968 & 0.289 & 2.188 \\
\hline \multirow{3}{*}{ Sienna-2 } & Interbeds & 2420.5 & 2455 & 34.5 & 8.99 & 0.26 & 0.33 & 0.23 & 2.09 & 0.55 & 0.94 \\
& Shale & 2455 & 2486 & 31 & 0 & 0 & 1 & 0 & 0 & 1 & 0 \\
& Core Sand & 2486 & 2502 & 16 & 14.17 & 0.89 & 0.1 & 0.3 & 4.23 & 0.22 & 3.31 \\
& TOTAL & 2420.5 & 2502 & 81.5 & 23.16 & 0.28 & 0.19 & 0.27 & 6.32 & 0.33 & 4.25
\end{tabular}

The depositional scenario started with an abandonment stage associated with maximum flooding. This early stage was followed by a fall in relative sea level that resulted in channel progradation particularly towards the west side of the field. The channels fan out towards the west and northwest forming sand bodies with small scale at the west (inner to mid fan) to wide scale, sheet like, at the northwest (outer fan). The east side was only dominated by mud-fill channels and flooding shale due to local changes in seas floor slope at that time (Figure 13).

Progradtional phase widened with time and resulted in accumulation of laterally amalgamated and vertically stacked sinusoidal channels. The final stage in Sienna channel evolution is represented by abandonment phase associated with another local flooding event.

SimSat-P1 and SimSat-P2 reservoirs form isolated sheet-like sand bodies as indicated from the horizontal time slices (Figure 14 and Figure 15). These sheet-like sand bodies form most probably relics of fan deposi- 


\section{Sienna Field Channel Evolution Stages}
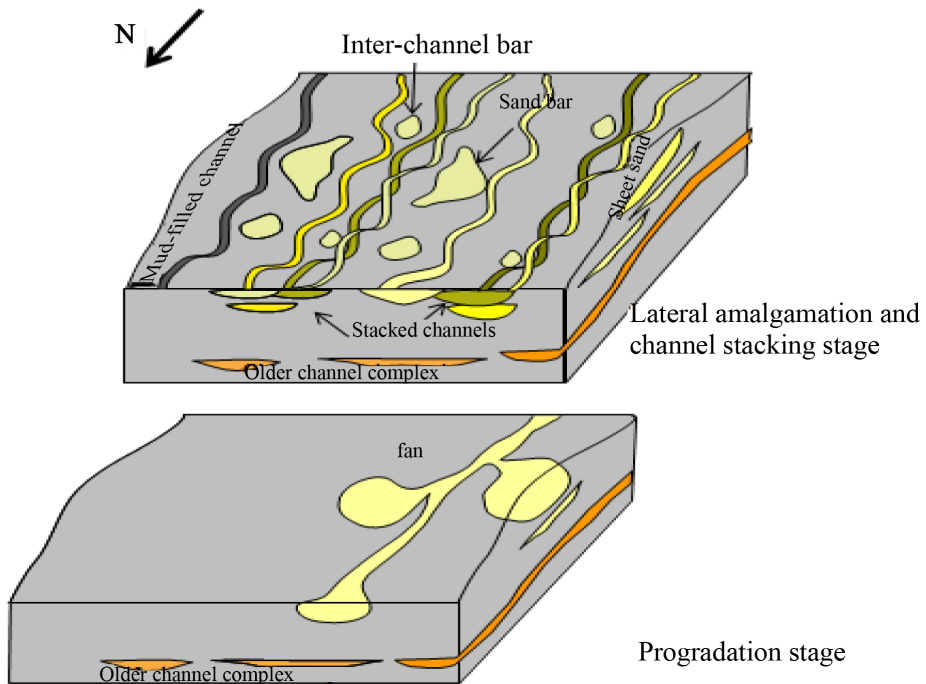

Progradation stage

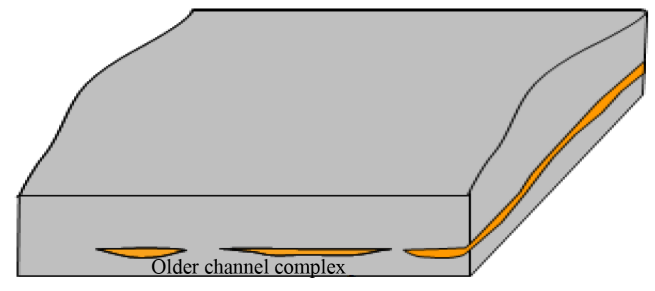

Abandonment and maximum flooding stage

Figure 13. Sienna channel complex evolution stages.
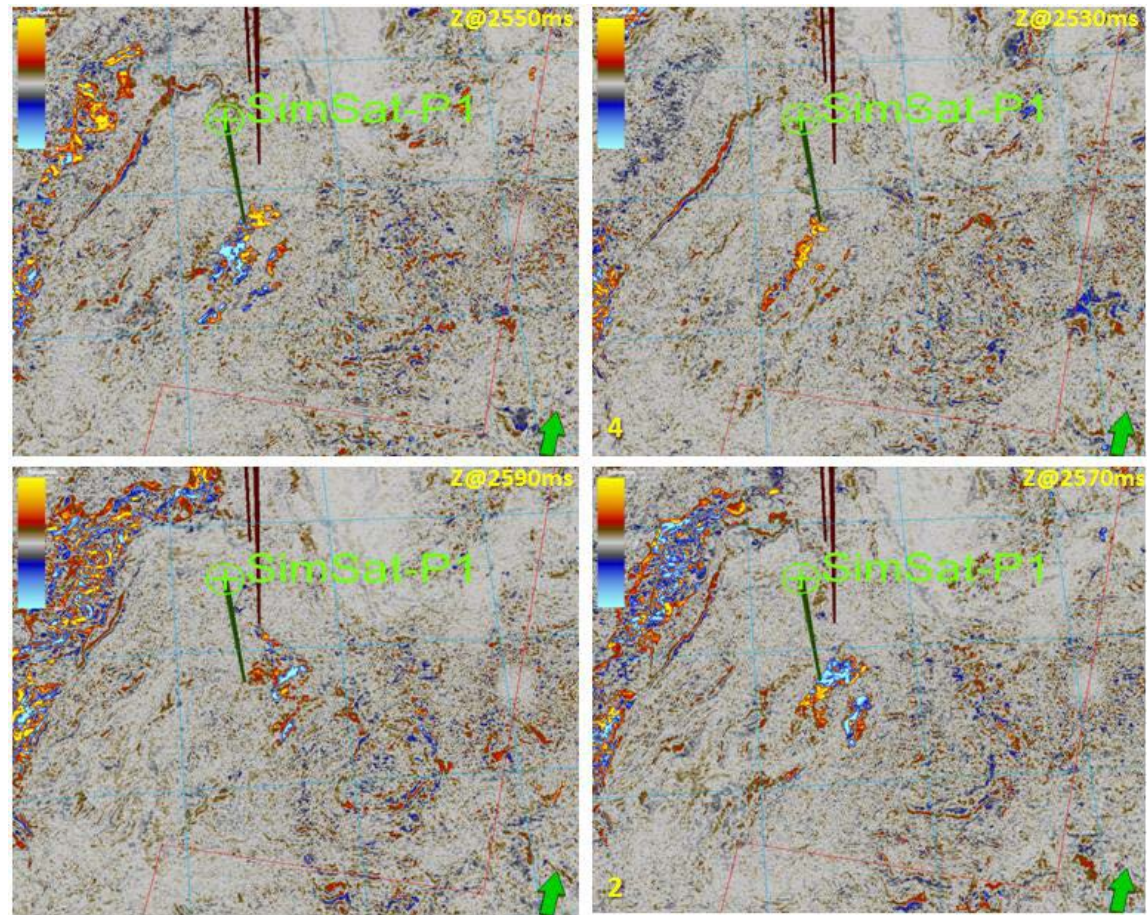

Figure 14. Seismic time slices showing the spatial distribution of seismic amplitude over the SimSat-P1 reservoir generated over interval with $20 \mathrm{~ms}$ time increment. 

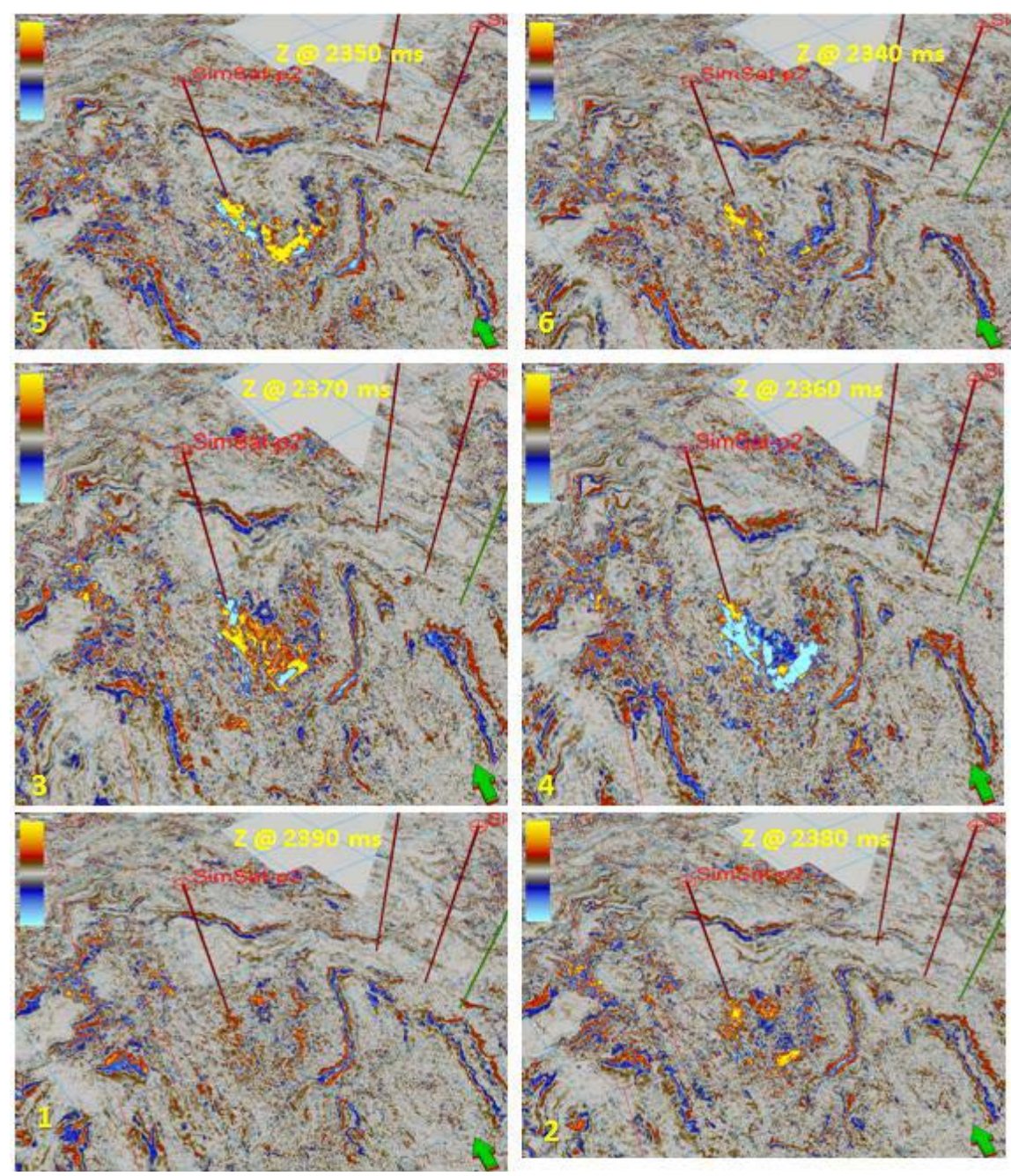

Figure 15. Seismic time slices showing the spatial distribution of seismic amplitude over the SimSat-P2 reservoir generated over interval with $10 \mathrm{~ms}$ time increment.

tional setting. The depositional setting started with flooding event resulted in pre-fan background mudstone and shale deposition followed by progradational phase and deposition of proximal, inner and mid fan deposits. Another flooding stage was followed and resulted in deposition of finer grained, sandstone and mudstone beds of outer fan setting followed by post fan shale beds that indicate the end of the final flooding event.

\section{Conclusions}

High-resolution seismic coverage of the SimSat-Sienna fields (West Delta Deep Marine Concession) provides a unique 3-D insight into the sand-body makeup, depositional evolution, and overall reservoir architecture of the submarine slope channel systems. These upper Pliocene channel systems are characterized by a history of erosional and depositional stages probably related to sea level changes. These stages are represented by laterally amalgamated, vertically stacked and abandoned channel bodies. The results concluded can be used as a good analogue to other areas of the world where seismic data is either missing or not of the same resolution.

Integrating high resolution seismic imaging with well data, formation micro images, and core data have significantly contributed in understanding the characteristics and evolution of the studied reservoirs.

Sienna channel complex is represented by unconfined channel system with clearly defined evolution stages, most probably influenced by sea level oscillation. The reservoir is characterized by fine grain siltstones and sandstone interbedded with mudstones and shale that were accumulated in relatively low energy, slope environment. SimSat-P1 and SimSat-P2 reservoirs are characterized by sheet-like sand bodies that also reflect pro- 
gradational, retro-gradational and flooding events. SimSat-P1 and SimSatP-2 reservoirs represent low energy, less stacked and smaller sand body geometry compared to deeper (older) Pliocene Simian channel system which may indicate decline of energy regime and/or intensity of clastic sediment that the basin received with time.

\section{Acknowledgements}

The authors express their thanks to Petronas and Egyptian General Petroleum Corporation (EGPC) for the permission to publish this paper. We also thank Prof. Adam El Shahat, Geology Department at Mansoura University in Egypt for his revision of this paper. We express our gratitude to Prof. Mahmoud Kora, Geology Department at Mansoura University in Egypt for his constructive recommendations.

\section{References}

[1] Mayall, M. and Stewart, I. (2000) The Architecture of Turbidite Slope Channels. In: Weimer, P., Slatt, R.M., Coleman, J., Rosen, N.C., Nelson, H., Bouma, A.H., Styzen, M.J. and Lawrence, D.T., Eds., 20th Annual GCSSEPM Foundation Bob F. Perkins Research Conference 2000: Deep-Water Reservoirs of the World, Houston, 3-6 December 2000, 578-586.

[2] Pirmez, C., Beauboeuf, R.T., Friedmann, S.J. and Mohrig, D.C. (2000) Equilibrium Profile and Base Level in Submarine Channels: Examples from Late Pleistocene Systems and Implications for the Architecture of Deepwater Reservoirs. In: Weimer, P., Slatt, R.M., Coleman, J., Rosen, N.C., Nelson, H., Bouma, A.H., Styzen, M.J. and Lawrence, D.T., Eds., 20th Annual GCSSEPM Foundation Bob F. Perkins Research Conference 2000: Deep-Water Reservoirs of the World, Houston, 782-805.

[3] Jeanette, D., Garfield, T.R., Mohrig, D.C. and Cayley, G.T. (2000) The Interaction of Shelf Accommodation, Sediment Supply and Sea Level in Controlling the Facies, Architecture and Sequence Stacking Patterns of the Forties and Tay basin-Floor Fans, Central North Sea. In: Weimer, P., Slatt, R.M., Coleman, J., Rosen, N.C., Nelson, H., Bouma, A.H., Styzen, M.J. and Lawrence, D.T., Eds., 20th Annual GCSSEPM Foundation Bob F. Perkins Research Conference 2000: Deep-Water Reservoirs of the World, Houston, 3-6 December 2000, 402-421.

[4] Posamentier, H.W. and Kolla, V. (2003) Seismic Geomorphology and Stratigraphy of Depositional Elements in DeepWater Settings. Journal of Sedimentary Research, 73, 367-388. http://dx.doi.org/10.1306/111302730367

[5] Reading, H.G. and Richards, M. (1994) Turbidite System in Deep-Water Basin Margins Classified by Grain Size and Feeder System. American Association of Petroleum Geologists Bulletin, 78, 792-822.

[6] Mayall, M. and O’Bryne, C. (2002) Reservoir Prediction and Development Challenges in Turbidite Slope Channels. Offshore Technology Conference Proceedings, Contribution No. 14029, 10 p.

[7] Mayall, M., Jones, E. and Casey, M. (2006) Turbidite Channel Reservoirs-Key Elements in Facies Prediction and Effective Development. Marine and Petroleum Geology, 23, 821-841.

[8] Samuel, A., Kneller, B., Raslan, S., Sharp, A. and Parsons, C. (2003) Prolific Deep-Marine Slope Channels of the Nile Delta, Egypt. American Association of Petroleum Geologists Bulletin, 87, 541-560.

[9] Boucher, J., Dolson, J. and Heppard, P. (2004) Key Challenges to Realizing Full Potential in an Emerging Giant Gas Province: Nile Delta/Mediterranean Offshore, Deep water, Egypt. (Unpublished Talk Presented at the HGS International Explorationists Dinner Meeting on 20 September, 2004).

[10] Said, B., Fahmi, R., Heath, M., Ahmed, D., Paul, O., Gawad, A. and Darwish, M. (2004) Simian Field Reservoir Modeling-Case for Classic Slope Channel Turbidite-WDDM Concession, Offshore Nile Delta, Egypt.

[11] Kamal, M., Barsoum, K., Aiolfi, C. and Dalla, S. (1998) Evolution and Hydrocarbon Occurrence in the Plio-Pleistocene Succession of the Egyptian Mediterranean Margin: Examples from the Nile Delta. Institutfrançais de pétrologie, 18, 1520-1535.

[12] Sarhan, M. and Hemdan, K. (1994) North Nile Delta Structural Setting and Trapping Mechanism, Egypt. Proceedings of the 12th Petroleum Conference of EGPC, Cairo, 12, 1-18.

[13] Schlumberger (1984) Chapter 1: Geolology of Egypt. Well Evaluation Conference, 1-64.

[14] Cowan, G., Swallow, J., Charalambides, P., Lynch, S., Dearlove, M., Sobhani, K., Nashaat, M., Loudon, E., Maddox, S., Coolen, P. and Houston, R. (1998) The Rosetta P1 Field: A Fast Track Development Case Study, Nile Delta, Egypt. Proceedings of the 14th Petroleum Conference, Vol. 1, 222-235.

[15] Barakat, M.G. (1982) General Review of the Petroliferous Provinces of Egypt with Special Emphasis on Their Geological Setting and Oil Potentialities. Cairo University, Cairo, 87 p.

[16] Saller, A.H., Noah, J.T., Ruzuar, A.P. and Schneider, R. (2004) Linked Lowstand Delta to Basin-Floor Deposition, Offshore Indonesia: An Analog for Deep-Water Systems. American Association of Petroleum Geologists Bulletin, 88, 21-46.

[17] Cook, T.W., Bouma, A.H., Chapin, M.A. and Zhu, H. (1994) Facies Architecture and Reservoir Characterization of a 
Submarine Fan Channel Complex, Jackfork Formation, Arkansas. In: Weimer, P., Bouma, A. H. and Perkins, B.F., Eds., Submarine Fans and Turbidite Systems: Sequence Stratigraphy, Reservoir Architecture and Production Characteristics, Gulf of Mexico and International. 15th Annual Research Conference of the Gulf Coast Section SEPM, 69-81.

[18] EREX (2002) Biostratigraphic and Lithostratigraphic Interpretation of Sienna-1 and Sienna-2. Unpublished Well Report.

[19] Cross, N.E., Cunningham, A., Cook, R.J., Taha, A., Esmaiel, E. and Swidan, N.E. (2009) Three-Dimensional Seismic Geomorphology of a Deep-Water Slope-Channel System: The Sequoia Field, Offshore West Nile Delta, Egypt. American Association of Petroleum Geologists Bulletin, 93, 1063-1086. 
Scientific Research Publishing (SCIRP) is one of the largest Open Access journal publishers. It is currently publishing more than 200 open access, online, peer-reviewed journals covering a wide range of academic disciplines. SCIRP serves the worldwide academic communities and contributes to the progress and application of science with its publication.

Other selected journals from SCIRP are listed as below. Submit your manuscript to us via either submit@scirp.org or Online Submission Portal.
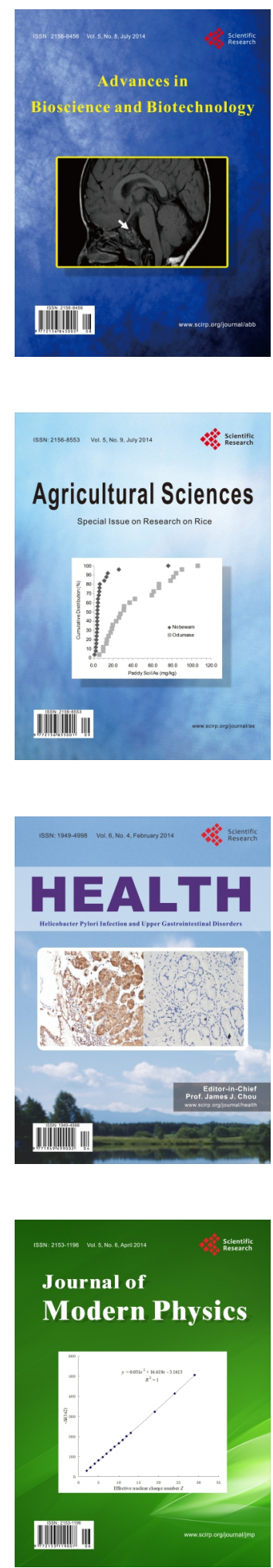
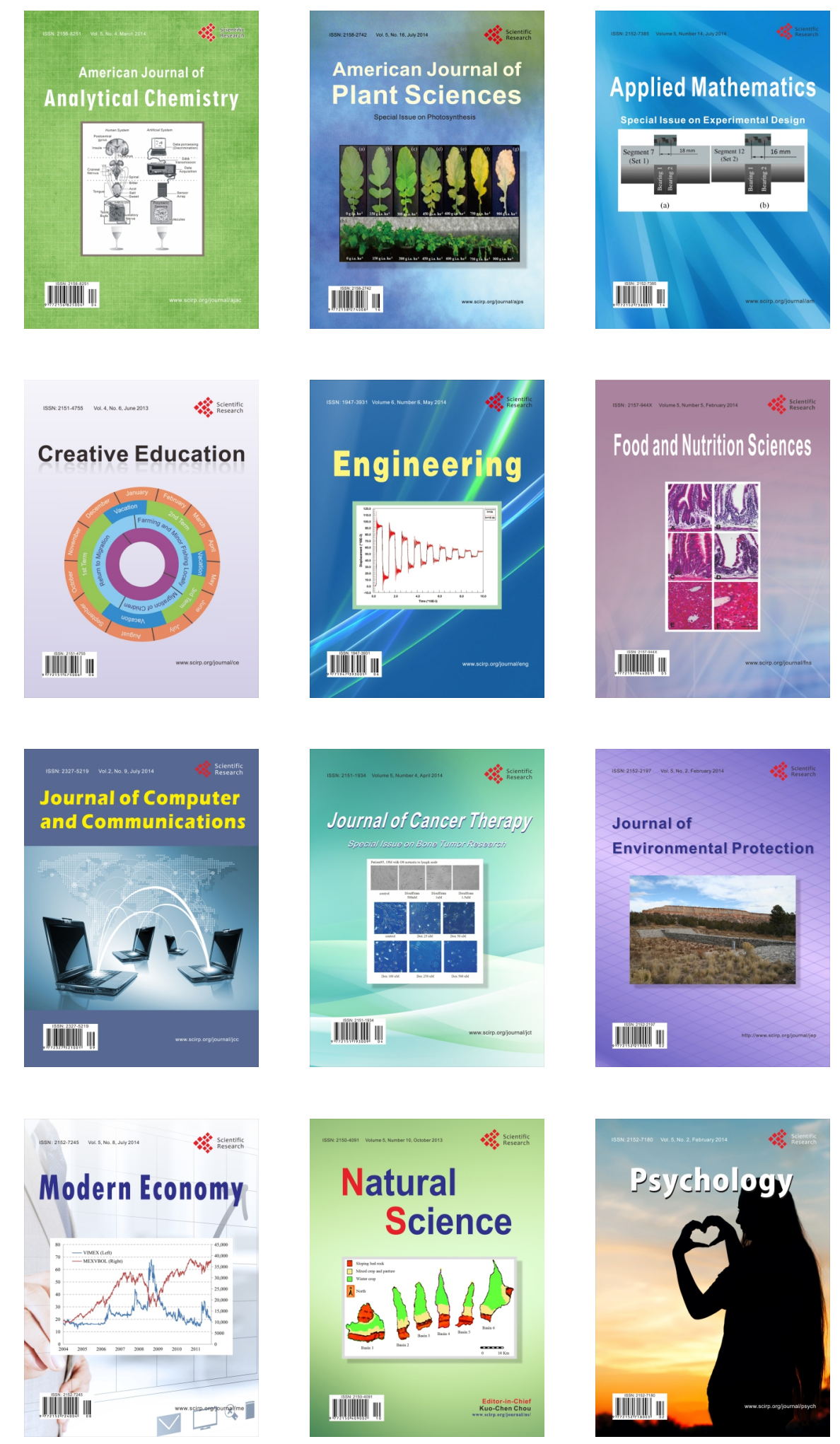